\title{
Ancestral beliefs in modern cultural and religious practices - The case of the Bapedi tribe
}

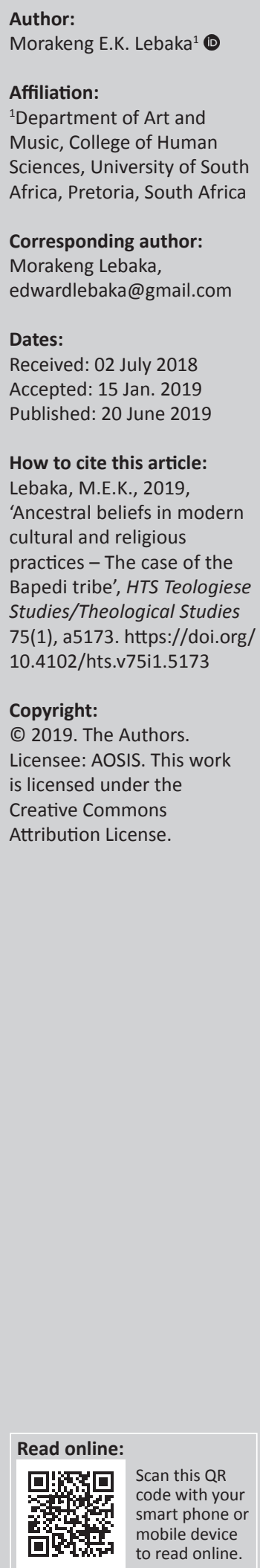

There is no consensus among scholars of myth as to how the central concept of their field should be defined. What is a 'myth' and how does it differ from a 'belief'? Moreover, scholars have argued for a homological relationship between myth and ritual. Semantically, the word 'myth' has a connotation of disbelief in 'superstition', and the word 'belief' should be substituted when talking about religious practices. Likewise, the word 'ritual' may be substituted with 'ceremonial', which has connotations that are more positive. Earlier publications that associate ancestral veneration with the words 'myth' or 'superstition' display a judgemental view of the beliefs of other cultures. In this article, the author attempts, via recourse to the use of the word 'myth', to describe and interpret traditional and cultural belief systems among the Bapedi people of Limpopo Province in South Africa. It is argued that myth should not be reduced to ritual nor ritual to myth. Belief and ritual, in Bapedi religion and belief systems, complete and complement each other, thus allowing the harmonious unison of meta and paralinguistic elements in religiocultural discourse. The focus of this study is to explore and document these links within the context of the Bapedi culture.

Keywords: Pedi; Religiocultural discourse; Belief systems; Ancestor veneration; Myths; Rituals.

\section{Introduction}

Myths ${ }^{1}$ and oral history are integral elements of Bapedi culture. The ancestral beliefs of the people are associated with myths, traditional and cultural beliefs, taboos and rituals. They are based on the experiences of ancestors and play a prominent role in the Bapedi understanding of reality. Bapedi people use ancestral beliefs to preserve their cultural heritage and identity and to transmit the valued moral education of Bapedi society across generations through origin stories, explanatory stories and didactic stories. In Bapedi culture, ancestral beliefs contain and express Bapedi culture and history. Jaja (2014) endorses these views and states that:

$[M] y$ ths encode the traditional settings of the Africans and their belief systems and portray the African ${ }^{2}$ way of thinking and as vehicles for preserving and transmitting valued knowledge of philosophical and moral truths. (p. 9)

Bapedi people observe their culture by exercising their spirituality, ${ }^{3}$ religious beliefs and taboo systems almost on a daily basis. Indigenous Bapedi spirituality involves rituals, beliefs and practices, perception, values and attitudes based on ancestors' experiences. This is in consonance with Omatseye and Emeriewen's (2010:543) argument, which asserts that Africans as a people have a philosophical system that may not necessarily be the same as that of other peoples. They point out that reflection on traditional African society encompasses their way of life and living environment (Omatseye \& Emeriewen 2010:542). While acknowledging that Bapedi people observe their ancestral beliefs to transmit their people's philosophy and values and to preserve their cultural heritage, it is concerning that such a small proportion of converts have relinquished their indigenous practices and beliefs as the consequence of acculturation. Among the Bapedi people, the preservation of cultural heritage is a group phenomenon. Because communalism is encouraged in Bapedi culture, there are myths ${ }^{4}$ disseminated across Sekhukhune District to

1.For S. Gumo et al. (2012:529), 'myths' refer to the historical explanations about the origin of a people, their traditional customs and beliefs as practiced by various African communities.

2.'African' in the context of this study refers to African (black) people who are residents of South Africa and fall within the Zulu, Xhosa, Sotho, Tsonga and Venda ethnic groups. Furthermore, 'African' in this context excludes the white, mixed race and Indian populations residing in South Africa. The exclusion of white, mixed race and Indian people from the African worldview is based on the understanding that these racial groups have their own unique and distinct worldviews, which deserve a separate in-depth enquiry (Thabede 2008:233).

3.Gumo et al. (2012:525), for example, provide a convincing description of spirituality in the African context. They observe that on the communal level, 'spirituality' may be used to refer to the shared 'ultimate values' and ideals promoted by a particular group or tradition.

4.Gumo et al. (2012:525) add further insight to the understanding of African worldviews and myths. They observe that in African worldviews, myths include cosmic, theogonic, anthropogenic and stereological myths. In their view, 'myths' refer to the historical explanations about the origin of a people, their traditional customs and beliefs as practised by various African communities. 
remind the Bapedi people about their ancestral beliefs and practices. Myths are categorised into three kinds of stories, namely, origin stories, explanatory stories and didactic stories. For the purpose of this study, while highlighting indigenous Bapedi spirituality, these categories will be fully discussed.

The purpose of this study was threefold, (1) to explore and document the links between myth and belief, myth and ritual, and belief and ritual; (2) to investigate ancestral beliefs in Bapedi modern cultural practices in relation to the African worldview and African spirituality; and (3) to determine how supernatural experiences link to reality through traditional and cultural experience of the world, specifically within the context of Bapedi myths and beliefs. Three interrelated research questions therefore guided this study, (1) What is a myth and how does it differ from a belief? (2) What is the cultural relevance of ancestral beliefs in contemporary Bapedi society? (3) How do ancestral beliefs relate to modern Bapedi cultural practices? To address these questions, three major categories of stories (origin stories, didactic stories and explanatory stories) in Bapedi culture will be discussed. These stories emerged from observations, interviews and analysed research data.

\section{Theoretical background}

The present study is based on the theory of Afrocentricity: The Theory of Social Change as proposed by Asante (1987), which views African cultural beliefs, practices and values as the basis of the African-centred or Afrocentric worldview. Asante provides an Afrocentricity theory grounded in the African context. He argues that Africans should view phenomena from the vantage point of an African worldview that is in turn informed by African culture. He observes that an Afrocentric worldview or the African-centred worldview is based on African cultural beliefs, practices and values. According to Asante, Afrocentricity implies the placement of African culture at the centre of any analysis that involves the study of African people. In his view, Afrocentricity is a perspective that allows Africans to be subjects of historical experiences rather than objects on the fringes of Europe (Asante 1999:111). Further, Asante elaborates that culturebased indigenous knowledge should reflect the customs, beliefs, values, knowledge, habits, skills, arts and way of life of African people. In this study, it was found that culture-based indigenous knowledge, which involves customs, beliefs, values, skills and arts, is reflected in the Bapedi way of life.

However, this research is distinguished from Asante (1987) thematically and contextually as evidenced by the variation of study subjects. Asante's model has the strengths of being contextual and interrogating relevant questions challenging African people. Moreover, because this approach interacts with historical and cultural contexts, it can be easily adapted to different African environments. Asante's theory enriches the concept of 'spiritualism' in the African context and engages in the African worldview, culture and life experience as a vantage point for the interpretation of African spirituality. My interpretation of this model in relation to the Bapedi cultural context is that the indigenous Bapedi religion, which involves cultural and religious beliefs, practices, attitudes and deeper human values, is spiritually based. The theory is applicable to this study because in Bapedi culture, myths, religious and cultural beliefs, taboos, sacred rites and rituals provide guidance for the philosophy of resource conservation, utilisation and environmental protection. This theory also assisted in determining how the religion of Bapedi people links to the spiritual ancestral realm. Asante's assertion of the Afrocentric paradigm, which deals with the question of African identity, is further enriched by Santos' (2012:6) argument that 'the values, beliefs and attitudes held by a group of people cultivate both an identity for themselves as well as an orderliness to everyday life'. In her research, 'Theories of culture, identity, and ethnomusicology', Alyssa Santos found that 'through various forms of socialization and upbringing, people are able to place things around them into categories and draw conclusions about the process of life'.

According to Mkabela (2005:179), the Afrocentric method suggests cultural and social immersion as opposed to scientific distance as the best approach to understand African phenomena. In her view, this means that the researcher must have some familiarity with the history, language, philosophy and myths of the people under study. Choice of the Bapedi people as the context for this research study was primarily motivated by the fact that the researcher belongs to the same group and is familiar with the history, language, philosophy and myths of the Bapedi people. Given this reality, it was very easy for him to investigate ancestral beliefs in modern Bapedi cultural and religious practices. The second reason for choosing this topic relates to the researcher's past experiences.

The theory of Afrocentricity questions the implementation of the Afrocentric paradigm by researchers. In his view, Asante and Asante (1985) and Asante $(1987,1999)$ emphasises that if the research is to be considered as a paradigm, the African indigenous people must be in control of and participate in the entire research process, from the beginning to end. This is precisely what happened in this study. The subjects for this study were interviewed using Sepedi, a local dialect. The researcher attended different Bapedi religious rituals and other relevant events that would further the understanding of the Bapedi people's ancestral beliefs and religious practices. At these rituals and events, the subjects were actively involved. As firmly as Asante argues that 'all cultural centers must be respected', the Bapedi people respect all their cultural centres and utilise their natural environmental resources for their spirituality in various ways. Asante's inclusion of African identity in his Afrocentric paradigm serves to explain and justify why the people under study should be centred, located, oriented and grounded. Thus, in this study, the subjects under study are centred, located, oriented and grounded. 


\section{Previous related studies}

Reviewing a number of African studies of African culture and values, several researchers such as Asante and Asante (1985), Asante (1987, 1999), Axelsson (1984), Ekore and Lanre-Abass (2016), Gumo et al. (2012), Idang (2015), Jaja (2014), Manala (2004), Mekada (1999) and Thabede (2008) have paid a great deal of attention to African culture, values and ancestral beliefs in African cultural practices. An overview of the relationship between the African culture, spirituality, belief system and value system is given in Omatseye and Emeriewen's (2010:530) study 'An appraisal of religious art and symbolic beliefs in the traditional African context'. In approximation to the present study, Omatseye and Emeriewen observe that 'in Africa, by virtue of their belief system, their spiritual practices have led to the creation of new artistic imageries'. They argue that African religion as a way of life can also be celebrated in the different stages of a person's life, for instance, birth, marriage, circumcision and initiations, annual festivals, death and burial (Omatseye \& Emeriewen 2010:534). In consonance with these observations, Gumo et al. (2012:535) assert that taboos in African communities commonly touch on all important aspects of life. According to them, they are associated with birth, initiation, marriage, food, death, socialisation, economic activities, agriculture and hunting. They further state that among the functions of taboos in African community is natural environment resource conservation (Gumo et al. 2012:536). Their findings indicate that, by use of taboos, natural environmental resource utilisation is conserved.

Attesting to these observations, Jaja (2014:11) writes: 'African philosophy is a reflection based on ancestors and cannot operate in a vacuum'. In his view, myths provide the necessary analytic and conceptual framework for an authentic African philosophy. He advocates that they constitute expressions of the inner side of individuals and their relationship with others, nature and with the supernatural. This is further articulated by Idang (2015), who says:

[... C]ulture is to be understood as the way of life of a people, and values are to be understood as beliefs that are held about what is right and wrong and what is important in life. (p. 98)

Adding to this, Thabede (2008:238) supports these observations by emphasising: '... arguing that African people share a similar culture does not necessarily mean that there are no diverging experiences among Africans'. Thabede (2008:238), however, has cogently argued: ' ... indeed, there are differences, but they are not as great as the Africans' difference from Europeans or Asians'. It is also in the same vein that Gumo et al. (2012) in a careful assessment of 'Communicating African spirituality through ecology' argues: 'the adoption of current lifestyles has endangered African spirituality in the conservation of the natural environment'. They point out that 'people have diverted their minds towards the new lifestyles at the expense of their indigenous beliefs and practices'. This is attributed to the lack of communalism in the African culture, which brought all into one single community of believers, propagating the same cultural ties and practices (Gumo et al. 2012:537). They further comprehend that African religion should not be ignored because it infiltrates deep into people's attitudes and consumerism patterns.

\section{Method and research design}

This research has endeavoured to utilise interviews and observation methods to supplement a literature study. Both oral interviews and observations were employed to gather data. Most of the interviews were informal and spontaneous. However, the researcher also carried out other interviews that were longer, more formal and in some instances taped. Virtually all the interviewing, formal and informal, revolved around questions emerging from the researcher's observations. Ultimately, the research is an investigation of the ancestral beliefs in Bapedi modern cultural practices in relation to the African worldview and African spirituality. The subjects for this study were interviewed (using Sepedi, a local dialect) independently from each other, in the confines of their respective homes. They were identified because of their knowledgeable and informative qualities. Specific ethnographic data were collected from five villages, namely, Kotsiri, Dingwane, Ga-Maloma, Mashite and Ga-Mashegoane. These villages are located in Schoonoord, in Sekhukhune District, approximately $15 \mathrm{~km}$ east of Jane Furse. The sample group of participants consisted of a village headman, knowledgeable elderly people in these communities, traditional healers and their trainees. The researcher also attended different malopo rituals (ancestor veneration; see Figure 1) and other relevant events that would further his understanding of 'belief and ritual' in the Bapedi religion and belief systems.

The study is contextual as it considers the local context (Bapedi society). The contextual approach has led to the achievement of the research objectives. This approach is supported by Reck, Slobin and Titon (1992:444), who argue that although we may travel to faraway places to meet, see and relate to unfamiliar things and people, or search for marvellous treasures, 'the pot of gold is buried in one's own backyard'. They encourage researchers to seek out nearby musical cultures, which they can observe, understand and document, in order to contribute to the body of knowledge on musical activities generally. What follows are the categories of stories found in Bapedi society, as articulated and practiced by the Bapedi people. This article presents these in the Bapedi cultural context.

\section{Results}

\section{Interpretation of myths, religious and cultural beliefs, taboos and rituals in Bapedi society}

Findings are presented in line with the study objectives for clarity. Necessary inferences are drawn from some findings in the light of the theoretical framework for the study. The article will now examine the different categories of stories in Bapedi society. 


\section{Origin stories}

\section{Mythical plants}

Indigenous trees of both medicinal and sacred importance mokaula, monamane, lengana, monoko maropane, marotela ditšhoši, mosehla (medicinal) and fera, morekuri, motšhidi, mošitšane, mmilo (sacred) - are found in Bapedi society, and Bapedi people are prohibited to cut down any of these trees, as they belong to the ancestors. Cutting down a tree is an offence punishable by customary law at the chief's discretion. Conservation of these trees is important to the Bapedi people. They use them for sacred, medicinal and ritual purposes. Supporting this, Idang $(2015: 108)$ states: 'it is part of the African world-view to treat the environment in which he [sic] finds himself with respect'. He further asserts that the African cooperates with nature and does not try to conquer it. According to him, this practice, whether founded on myth or not, had a way of preserving and conserving nature. Bapedi traditional healers consider marobadigale 5 [witchcraft mystical forces fighter] and fera to be the most important medicinal trees found in Bapedi society. According to Madikedike Simon Sete, a senior traditional healer (pers. comm., 18 December 2017), some if not all Bapedi traditional healers hold that the leaves, barks and roots of the marobadigale tree can be used to cure 37 health-related problems or ailments, ${ }^{6}$ giving it the name marobadigale. This finding is in partial agreement with that noted by Semenya and Potgieter (2014:8). In a careful assessment of the significance of plant species in the Bapedi cultural context, they found that the leaves were the morphological plant part most preferred in the preparation of remedies, followed by the roots and bark.

\section{Mythical animals and reptiles}

Wild and domestic animals and reptiles are found in Bapedi society. Cattle, sheep and goats constitute human food and their importance is obviously great, and they may also be accorded religious and sacrificial significance, especially during ancestor veneration and other rituals. A considerable number of traditional healers in Bapedi society regard phiri [hyena], tshwene [baboon], kgabo [monkey], noko [porcupine], tau [lion] and so on as mythic animals and noga [snake], kwena [crocodile] as mythic reptiles. However, some snakes and baboons are associated with witchcraft. According to Madikedike Simon Sete, some traditional healers consider the baboon, hyena and porcupine to be the most important animals, with both medicinal and religious significance. This belief is strongly held, and some traditional healers continue to use the bones of these animals as part of their divination and to utilise some parts for medicinal purposes. This strong

5.Marobadigale is also known as makgonatsohle.

6.Thirty-six health-related problems or ailments were found to be treated by marobadigale. Such problems and ailments include, among others: abortion, appetite, asthma, blood clotting, body pain, breast cancer, sexually transmitted infections (chlamydia, gonorrhoea, HIV and AIDS), chronic diseases of lifestyle infections (chlamydia, gonorrhoea, HIV and AIDS), chronic diseases of lifestyle
(diabetes mellitus and hypertension), circumcision wounds, contaminated blood, depression, diarrhoea, epilepsy, erectile dysfunction, eye infection, female infertility, goiter, heart problems, kidney problems, leukaemia, low sperm coun malaria, measles, menstrual disorders, mental illness (insanity), nose bleeding period pains, stomach complaints, stroke, swollen legs, tonsils, tuberculosis and womb problems. belief in the medicinal significance of both the baboon and hyena appears to be universal to all traditional healers found in Bapedi society. Solly Lekwana (pers. comm., 19 December 2017) confirms that traditional healing among Bapedi traditional healers is deeply rooted in the use of animals, plant species, reptiles and others.

\section{Mythical rites}

Circumcision: In Bapedi society, initiation is a major rite of passage that preserves the Bapedi cultural heritage. Initiation has been carried forward from one generation to another, by the forebears of the present generation of Bapedi people. Over time, the Bapedi have conserved specific geographical sites for special rites, such as circumcision, worship and hunting. In all the villages, on the mountains, there are spaces set aside for initiation schools. These sites are protected by a series of taboos. People are prevented from going to these sites, as it is believed that they might be cursed. This view is endorsed by Gumo et al. (2012:535), who comment: 'ancestral spirits are regarded as guardians of natural environmental resources'. They further mention: 'if one destroys what is portended as sacred, ancestors will punish him or her with either death or misfortune'. These views are supported by Idang (2015), who states:

African culture is embedded in strong moral considerations and has a system of various beliefs and customs which every individual ought to keep in order to live longer and to avoid bringing curses on them and others. (p. 103)

Idang's observation is supported by Morongwa Angelinah Tshehla (pers. comm., 19 December 2017), who asserts: 'in Bapedi culture, beliefs and customs touch on all important aspects of life and are employed as techniques to understanding social structure and processes'.

\section{Shrines}

In Bapedi society, the land is spiritually utilised by making libations and pouring blood, water, beer and putting snuff tobacco onto the ground as sacrifices to appease the ancestors (see Figure 1). Each personal ancestor has sacred objects that are dedicated individually to them.

Indigenous Bapedi spirituality according to Magane Amos (pers. comm., 17 December 2017) is expressed in shrines and sacred places where sacrifices can be offered to appease the ancestors. According to him, some shrines belong to a family, such as those connected with the departed family members or their graves. Others belong to the community and are often located at the royal place [moshate]. The chief and his representatives protect such places from misuse by unauthorised community members. During a personal interview with Mashegoane Tswaledi Stephen (18 December 2017) at Dingwane Village, Sekhukhune District, he also pointed out that in Bapedi society, a shrine [sebatlabadimo] and sacred sites such as those for circumcision or initiation [mphatho] are protected and conserved for moral education and religious purposes. 


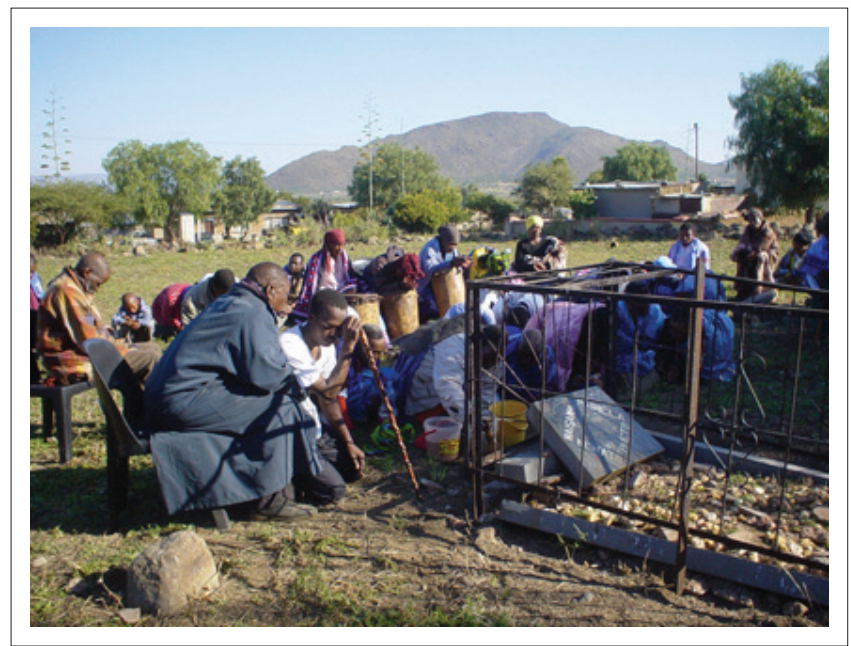

Source: Photo taken by Morakeng Edward Kenneth Lebaka

FIGURE 1: Dingaka [traditional healers] and mathasana [trainees] making libations and pouring beer onto the ground (Mashite Village - Schoonoord, Sekhukhune District, 29 September 2007).

\section{Death attributed to witchcraft}

\section{Witchcraft}

Bapedi people consult with traditional healers (see Figure 2) to protect and strengthen themselves against witchcraft.? This shows that among the Bapedi people, fear is one of the aspects linked to witchcraft. On the same note, Semenya and Letsosa (2013) elaborate:

$[M]$ any of the Basotho live with fear of being bewitched and, therefore, visit dingaka tsa setso (traditional doctors) ${ }^{8}$ to obtain traditional herbs to shield them or their property (family, house, car or animals) against witchcraft. (p. 3) ${ }^{9}$

They further observe that the fear arises from suspicion in most instances, and this suspicion then leads to hatred. According to them, hatred in turn leads to anger, which then leads to witchcraft.

Tau Ranapo supports this and gives a broader description of the African understanding of witchcraft ${ }^{10}$ as follows:

Witchcraft is always suspected, after any unexplained death in the Bapedi community. The immediate family of the deceased naturally wants to understand the cause of death Their reliable source of information is either traditional healers or diviners. If they consult a traditional healer, he or she will

7.In defining African witchcraft, Van Wyk (2004) writes that:

in defining African witchcraft, one could start by stating that in general African witches and sorcerers are people with the mystical ability to manipulate the forces of life to do harm to human beings or their property (p. 1210).

He further observes that most Africans also believe that people have the ability to manipulate these powers and forces to their own benefit and to the detriment of others.

8.The words for 'traditional healer' in indigenous South African languages are ngaka (Sepedi), gqira (Xhosa), inyanga (Zulu), nanga (Tshivenda) (Thabede 2008:242).

9.Semenya and Letsosa (2013:1) correctly state that 'Africans view witchcraft as something evil and potentially harmful to people'. According to them, it is therefore no surprise that anyone suspected of practising witchcraft within the community is immediately killed or harassed in different ways by members of the community.

10.According to Thabede (2008:241), witches or sorcerers are persons who use their power and the forces of nature to harm other people. Thabede further asserts that 'witchcraft is believed to be inherited'.

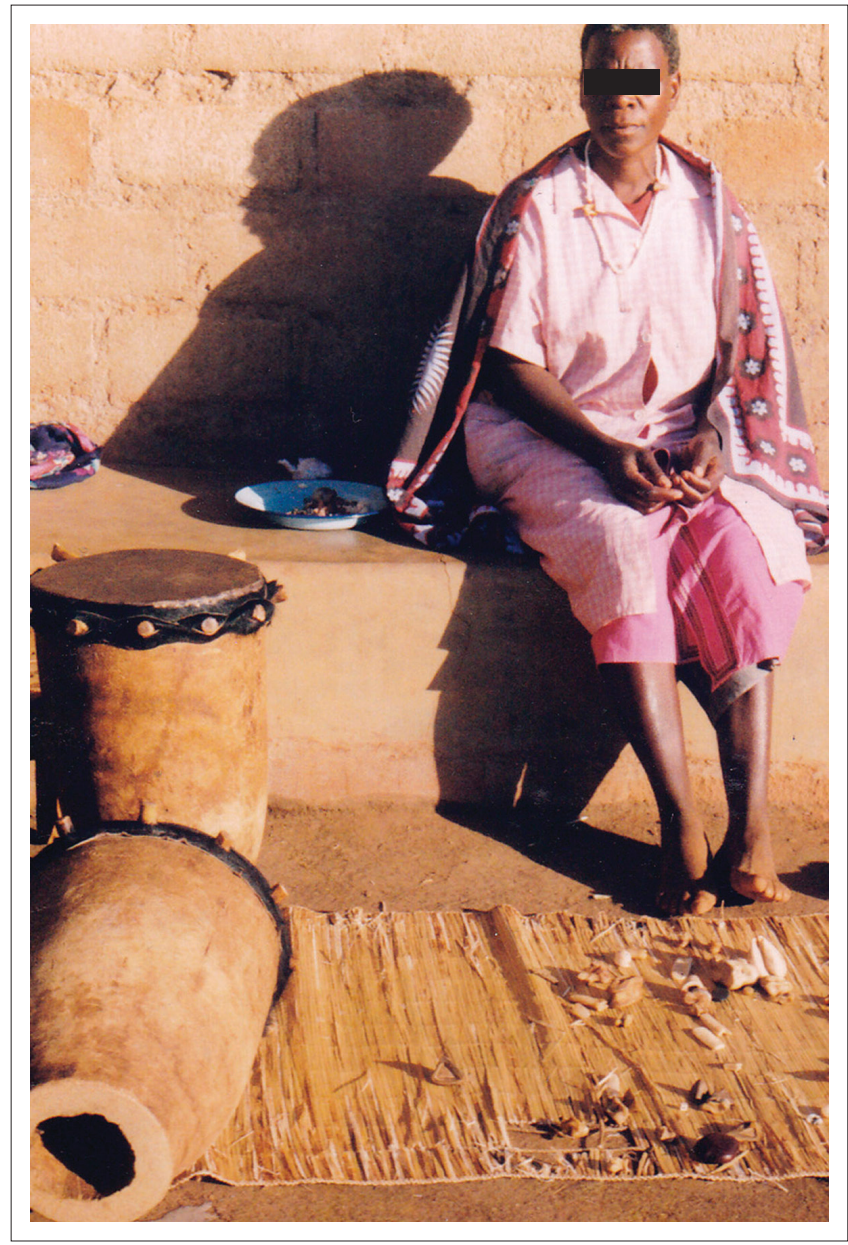

Source: Photo taken by Morakeng Edward Kenneth Lebaka

FIGURE 2: Traditional healer: Tau Ranapo and meropa [drums]. Utilisation of a set of divination bones (Kotsiri Village - Schoonoord, Sekhukhune District, 18 December 2017).

utilise divination bones to diagnose the cause of death, with some hope that either his or her ancestors or the client's ancestors will disclose the cause of death. In case the traditional healer discovers that the deceased is bewitched, the traditional healer may avenge the death on behalf of the deceased. It is expected that the perpetrator will die, or become mentally deranged and disclose to the community what he or she has done. (Tau Ranapo pers. comm., 17 December 2017)

In support of this viewpoint, Manala (2004:1500) states: 'in the African's world of thought, when ill-health, misfortune, accident or death occurs, traditional Africans will immediately probe witchcraft as the likely cause'. Manala (2004:1495) further mentions: 'witches are not only feared, but also hated because they make life unbearably difficult for individuals, families, communities and societies'. On the same note, Idang (2015:107) writes that most contemporary Africans find it difficult to adjust between their primitive beliefs in certain aspects of their culture and the supposedly modern mode of accepted behaviour. He further asks how the African explains disasters, deaths, accidents and other misfortunes in the family. In his view, a new convert of the Christian church would run to the church for explanation and comfort, but if the church's reaction is not immediate or 
prompt, the person may turn, in secret, to the native medicine man for immediate remedies. If the relief comes, he finds himself having to hold dual allegiance - one to his newfound faith and the other to his primitive beliefs. Leistner (2014:1) concurs with Manala (2004:1495) and Idang (2015:107) by commenting that 'most Africans (that is, black Africans) fear and hate witches and their craft as the embodiment of evil'. In his (Leistner 2014) view:

Where people live closely together and are inextricably dependent on one another, even if they hate each other, the possibilities for tension are unlimited. According to him, most frequently it is jealousy and envy that cause trouble. He mentions several examples. It is often the case between co-wives, where one feels that the other has been unfairly favoured by their husband. Jealousy may arise between mother and daughter-in-law if the latter's migrant husband sends her money rather than to the mother. A brother may be jealous of his more gifted brother, or success in farming may incite the envy of less successful neighbors.

On the same note, Van Wyk (2004:1216) observes: 'jealousy and envy drive people to accuse others of witchcraft'. He further mentions: 'witchcraft is as old as humanity itself'. In his view, throughout the ages, witchcraft has been one of the big problems of humanity'. In consonance with these views, Wallace $(2015: 4,5)$ observes that 'life experience is seldom unaccompanied by misfortune, affliction and adversity, each of which can occur in the physical, social and/or psychic dimensions'. He is concerned that African belief in the reality and dangers of witchcraft was described by missionaries and colonists as being an unbiblical position. I agree with these scholars because oral accounts and literature have revealed that people are accused of witchcraft because they are believed to inflict harm upon others through the use of mystical power.

\section{Burial ceremonies and mourning practices}

One other important function of Bapedi is the burial of their family members (Lebaka 2017:46). Usually the family takes complete charge, from the digging of the grave to the dressing of the corpse. Just before the burial, non-members, including the relations of the deceased, are not permitted to see the corpse. This has given rise to speculations that bodies are tampered with before they are buried. To remove this suspicion, these days the elderly people in the family invite relations of the deceased to inspect the body for the last time before the corpse is taken to the cemetery for burial. What is certain, however, is that Bapedi society gives its members elaborate and expensive burials. This fact accounts in no small measure for the popularity of Bapedi society, because the burials are highly celebrated affairs. Radio announcements are made repeatedly before the burial. Lebaka (2017) corroborates this when he observes that in Bapedi culture, the burial ceremony is a great forum for social relationships in Sekhukhune District. Lebaka opines that, in fact, the people see it as the greatest solidarity force, bringing many from near and far. In his view:

People who would not even come home for festivals might come to a burial ceremony, especially when death occurs in their families. Family and community members from different locations use this forum to introduce themselves and their young ones to one another and exchange addresses. Old friends and playmates who have lost contact for a long time often form a circle in re-union while the burial ceremony is in progress. All family members pay $[a]$ certain amount of money in order to assist the bereaved children, in some ways, to make the obsequies successful. Individuals also associate with the bereaved in cash and in moral support. The women often fetch a heap of firewood and sometimes contribute water and food such as mealie-meal, to assist the bereaved. (p. 46)

Ekore and Lanre-Abass (2016:369) endorse these observations by commenting that 'in African societies when death occurs, there is usually an impact on the family and friends of the deceased, the magnitude often depends on whether death was expected or unexpected'.

\section{Didactic stories}

\section{Taboos}

Widow or widower: In Bapedi society, taboos and beliefs preserve Bapedi cultural heritage and play an important role in the moral education of Bapedi history and religion. For example, among the Bapedi people, cohabiting with either a widow or widower is a taboo. ${ }^{11}$ Everyone is extremely cautious about it, and both men and women know very well that if they ignore the taboo they will definitely die. It is believed that the spirit of the dead affects the new partner of either the widow or widower and has human powers to harm the body, as well as to cause illness and death. For example, in the case of a man, as a new partner to the widow, after cohabiting with the widow, his belly will gradually become bigger and round, his legs will gradually become round and big, his manhood will also become gradually bigger. All these are the symptoms of death as the consequence of cohabiting with the widow.

Eventually, the victim will die. Very few traditional healers are specialists in this type of an illness or taboo. In a sense, very few people are ignorant of this taboo. This philosophy or ideology is, in large measure, the epitomised thought and feeling, of a community rather than an individual.

It is a cardinal belief of the Bapedi people that on entering any household, a widow should first request another widow to wash her feet with water mixed with cow dung. In a large sense, this caution goes back to people in the Bapedi culture themselves who came to the conclusion that ignoring this belief may result in the cows of the particular household having miscarriages.

\section{Death}

Death by shooting, stabbing or a car accident: A large portion of Bapedi society do not bring home the body of a

11. Gumo et al $(2012.541)$ endorse this observation by stating that a taboo is cultural or religious custom that forbids people not to do, touch, use or mention certain things or words. According to them, the word is derived from the Polynesian word tapu, meaning 'tied'. They are of the opinion that it refers to any ritual prohibition to which an automatic sanction - religious or magical - is attached. 
person who was shot to death, stabbed to death with a knife or any sharp instrument or was killed in a car accident. In Bapedi society, the night before the funeral, the body of the deceased is brought from the mortuary to his or her home for a night vigil, whereby friends, relatives and whoever is present pay their last respects in the form of speeches, songs and mourning. However, in the case of the aforementioned causes of death, the night vigil is conducted without the body of the deceased, as the body is taken directly from the mortuary to the cemetery the following day, where people can pay their last respects. This is because of a strong belief among the Bapedi that if the body of a person who had an unnatural death is brought home, a member of either the immediate family or the extended family will be killed in a similar manner. This finding is corroborated by an interview with Morongwa Angelinah Tshehla (Morongwa Angelinah Tshehla pers. comm., 18 December 2017), who is of the view that 'the death of such a person is usually believed to be caused by ignorance of taboos and ancestral beliefs by some families, but at times it is attributed to witchcraft'.

High accident zone: Many families in the Bapedi community have lost loved ones because of high accident zones, especially on the main public road. Many have died young. This includes both pedestrians, who are hit by cars, and motorists, whose cars collide or overturn. There is presently a righteous outcry against this high death rate in the Bapedi community. The chief is the focus of blame. Very often Bapedi people complain and protest to request the chief's intervention. In the past, after an accident had happened, the local chief would summon his special traditional healers to take away the spirits of the deceased by means of a ritual. The sole purpose of this was the avoidance of further accidents, especially on the scene or zone where the accident happened. This is because of the Bapedi belief that if the spirits of the departed are not taken away from the area, they could instigate reckless driving, accidents and the deaths of motorists, passengers and pedestrians in future. It is also believed that at times the spirits have a direct influence not on the driver but on the pedestrian, who in turn would be confused, thereby not crossing the road faster.

From this, it was concluded that the chief, by ignoring this, was responsible for many children being orphaned, as their parents died in these high accident zones. In addition, the chief's ignorance has led many families to perform their own clan or family rituals ${ }^{12}$ to reduce the number of accidents in these high accident zones. This view is endorsed by Malebo Sete (pers. comm., 19 December 2017), who states: 'unfortunately some people do not seem to realise the need for this ritual and are often subjected to incredible suffering because of negligence and ignorance'.

12.This observation is vividly corroborated by Gumo et al. (2012:542), who state that rituals in African communities are carried out at one's life at birth, initiation, marriage and death. They believe that rites of passage as a way of celebrating life accompany each stage of life. They further assert that most rituals entail the natural environment where people live.

\section{Explanatory stories}

\section{The birth and death of twins in the family}

Birth: In the Bapedi community, twins are considered to be very delicate, special and respected children. The belief acknowledges that twins are a rare phenomenon and should be acknowledged and treated specially in all respects. Contrary to this, Idang (2015) writes that 'prior to the arrival of Mary Mitchell Slessor (1848-1905) in Africa, ignorance, superstition and negative values made multiple births to be seen as a harbinger of evil'. According to Idang (2015):

[T] he birth of twins was seen as a very bad omen, and in order to save the community from the anger and wrath of the deities, the twins were killed together with their mothers. (p. 109)

On a positive note, Idang (2015:110) further mentions that 'since this custom was stopped by Mary Slessor, multiple births are now seen as multiple blessings'.

Death of one twin: During interviews and observations, it was established that in Bapedi culture there is a general belief that if a twin dies, during the burial ceremony, before the coffin of the dead twin is placed in the grave, the surviving twin must enter the grave and immediately get out. Attesting to this belief, Malebo Sete (pers. comm., 18 December 2017) confirms that 'ignoring this belief might cause the remaining twin to suffer mentally'. For example, this might negatively affect his or her scholastic results (not performing well at school), becoming forgetful and so on.

\section{Name-giving}

Those interviewed generally agreed that traditional names are a means of perpetuating Bapedi cultural heritage (Lebaka 2008:157). Naming children after their paternal or maternal relative is common practice. A child bears the name of his or her grandfather, grandmother or father or mother.

According to Lebaka (2008:158), the main value of this type of naming system is that the names link several generations together, thus bridging the long gap between grandparents and grandchildren. It also perpetuates the names of the ancestors and is a way of honouring them. By giving the grandparent's name to a child, it is believed that the ancestor will never die and also that the child may automatically inherit his or her ancestor's good virtues. Bapedi people generally believe that there is some special communication between ancestors who have died and that such ancestors are watching over their living relatives in order to protect them. There is a widespread belief in Bapedi culture that the names given to children also influence their future behaviour and achievement. Almost every name in Bapedi society has a meaning, and examples of how children's names are determined are given in the following list.

1. Where the child was born: If born in a foreign land, another city or a village far from home, a child may be called Motšwakgole [coming a long way; female]. If a child 
was born on the way to the hospital, the name could be Mmatseleng [born on the road; male or female].

2. The time or the exact condition at the time of birth of a child: If a child is born at a time when the family is blessed, the name could be Lethabo [joy; female], Mahlatse [blessing; female], Lerato [love; female], Lehumo [wealth; male]; Mmapula [rain's mother; female]; Dipuo [hearsay or gossip; female]; Mmaditaba [gossip's mother; female]; Tebelelo [tender loving care; female].

3. A way of expressing the state of mind of the parents: A child who is born immediately after his or her father or mother's death may be named to reflect such a condition of mind. Such a child may be regarded as a substitute or a compensation for the father or mother's death. Names in this scenario include Moiponi [forsaken; female]; Molahlegi [abandoned; female]; Sello [lament; male]; Dikeledi [tears; female]; Matshwenyego [going through difficult times or problems; female].

4. Expressing wishes, hopes or requests: Names may be a request for joy or success in life, a way to express what the parent wants a child to be. Among the Pedi people of the Sekhukhune area in Limpopo Province such names may include Lethabo [joy; female], Mahlogonolo [good luck; female], Mahlatse [blessing; female], Lerato [love; female] and Lehumo [wealth; male]. Such names have special power; not only can they influence the character of the child but can also provide or bring happiness to their homes.

5. Expressing gratitude to God, the divinities, ancestors or the parents of the newborn: Examples of these names among the Bapedi people are as follows: Kgodisho [praise; male], Tebogo [thanks or I thank you; male or female]; Mogau [grace or benediction; female]; Kearabilwe [I am blessed; male or female]; Kelello [I had a child accidentally; male or female]; Kgothatso [comfort; male or female]; Lebogang [thank Him, acknowledgement; male or female]; Reneilwe [gift; female]; Keneilwe [gift; female]; Mpho [gift; male or female]; Keabetšzue [I am blessed; female]; Refilwe [we are blessed, gift; female].

6. Advice to parents or the community to be patient, to endure or persevere: Names may reflect the values of patience, endurance and perseverance that the parents have endured in the past years of difficulty and pain; such a child may be called Kgotlelelo [patience; female], Reatlegile [we are blessed; male or female]; Rehomoditšwe [we are comforted; female]; Kgotsofalo [I am delighted; male] and others. Such names become a way of communication among the people.

7. Naming for times, days and years: Because the Bapedi people believe that the days of the week are sacred and each day has its special meanings, children may be named after the day of the week. A child born on Sunday may be named Sontaga [male or female]; on Friday may be called Labohlano and on Monday may be called Moshupologo [male].

In consonance with these observations, Mmotla Matshetla Sarah (pers. comm., 18 December 2017) makes the following statement with regard to name-giving in the Bapedi cultural context: leina le lebe ke seromo [a bad name is likely to negatively influence the character of the child]. Madikedike Simon Sete (pers. comm., 19 December 2017) adds further insight and cites the example of names such as Madimabe [bad luck; male]; Mathaithai [miracles; male]; Mpherefere [troublemaker; male]; Ntoagoloma [habitual fighter; male]; Selotsoko [something strange; male]; Matete [miracles or surprise; male]; Mahlomola [lonely or bewildered; male]; Sankgalakela [it is bitter; female]; Ntoengwe [something strange or amazing; male]; Ngwanamaru [child of the clouds; female]; Lekgotla [meeting or gathering; female];Monnakgoro [headman; male];Mmatsekutseku [fraudster; male]; and Mailagofenywa [skilful fighter or hero; male].

It cannot be disputed that Bapedi people attach a special significance to their names. Bapedi people do not have names like moon, sea, mountain or forest. According to oral accounts, the name-giving ceremonies are characterised by praise, gratitude and rejoicing. This belief in name-giving is undoubtedly insightful and of great value in communicating the identity of the tribe or clan from which one comes in particular and generally as a means of maintaining and preserving the Bapedi cultural heritage.

What has emerged thus far is that the Bapedi traditional religion is still a living reality; nevertheless, Bapedi people's religious and cultural practices have been influenced and are still being influenced by Christian beliefs and Christianity. The findings also imply that religious beliefs and values, with a related understanding of Bapedi people's cultural and religious practices, human relationships and morality, continue to flourish in the minds of Bapedi people. It is clear that the cultural relevance of ancestral beliefs in contemporary Bapedi society will be found chiefly in the area of conscious convergence between itself and Christianity.

Despite the divergent opinions on ancestral beliefs, it is evident that in Bapedi society, ancestral beliefs are not linked primarily to the individual. The whole community is influenced by religion, which also emphasises the collective functioning of Bapedi cultural practices. During interviews, interviewees were of the opinion that ancestors play an important and inherent part in the functioning of Bapedi cultural practices and a prominent role in protecting their people against harmful and destructive forces. Based on the findings of this study, it is evident that, in the Bapedi culture, ancestral beliefs influence all aspects of the day-to-day lives of many Bapedi people. Some of the ancestral beliefs and values encourage Bapedi people to be respectful and live in harmony. Furthermore, ancestral beliefs are often associated with Bapedi people's ceremonies and rituals.

During informal discussions and interviews, some participants highlighted that myths and rituals serve the same function, but they do not serve it together. They stated that myths reveal the way Bapedi people think, and that they have the same relationship to other myths as their parts have to one another. In answering the question, 'what is a myth and how does it differ from a belief?', the investigation has revealed that myths are simply stories and refer to familiar notions 
that purport to say something important about our lives. During informal discussions and interviews, it was also established that 'belief' is acceptance of a claim as truth regardless of supporting or contrary empirical evidence, while myth is a traditional story that embodies a belief regarding some fact or phenomena of experience and in which often the forces of nature and of the soul are personified. The participants in this study agreed that beliefs are held unconsciously, and most develop and transform over time.

\section{Discussion}

The present study has revealed that the belief in African culture and values, African spirituality, ancestors, witchcraft and myth is crucial to Bapedi religious and cultural life. Findings of this study show that Bapedi people in their traditional beliefs express their faith artistically in myths, taboos and rituals (songs, music and dance). With regard to cohesion, the enquiry has revealed that in Bapedi society, communalism is imperative and is regarded as a moral basis for interaction to jointly accomplish their cultural beliefs, customs and practices. Noteworthy is the fact that many people in Bapedi society still observe their culture and adhere to their traditional lifestyle and practices.

Based on the findings of this study, interpretation of the significance of the baboon and hyena reveals that, in Bapedi culture, some trees and animals are more important than others in terms of medicinal, sacred and ritualistic significance. The investigation suggests that, in Bapedi society, fear is one of the aspects linked to witchcraft, and witchcraft is viewed as a threat to the community. When ill health, misfortune, accident or death occurs, witchcraft is suspected to be the likely cause, and traditional healers are consulted for confirmation. Within the context of this study, this suggests that Bapedi people live with the fear of being bewitched. Similar to my argument, Manala (2004:1500) asserts that witchcraft victimises black Africans, including Christians, and has a negative influence on their lives. He further stresses that both traditional culture and worldview dominate the African view of illness and health matters. According to Manala (2004:1499), this description is a testament that from both an African culture and worldview perspective, there is no illness of which witchcraft is not the cause.

On the basis of these findings and discussions, it is evident that the use of some plant species by Bapedi traditional healers to treat a considerable number of health-related problems in Bapedi society strengthens the fact that indigenous medicinal plants have the potential to satisfy the varied health care needs of Bapedi people, and therefore it is imperative to conserve and protect the natural resources such as plants, sites, animals and so on. The exposition of this study has shown that documentation and understanding of ancestral beliefs in modern Bapedi cultural practices is crucial, as it might provide solutions to future challenges of diseases, deaths, bad luck or curses from the ancestors. African spirituality can also contribute to the conservation of useful trees, animals, sites and reptiles. The impression created during interviews and observations was that in Bapedi society, indigenous knowledge systems have been handed down by their forebears from generation to generation through oral tradition and have enabled Bapedi people to survive and manage their natural resources. During interviews and observations, it was also established that Bapedi society has a relatively rich body of indigenous knowledge about environmental conservation.

This discussion has highlighted, (1) the links between myth and belief, myth and ritual, and belief and ritual; (2) the interpretation of myths, traditional and religious beliefs, taboos and rituals in the Bapedi cultural context; (3) how values occupy a central place in Bapedi culture as a heritage that is practised and passed on to succeeding generations; and (4) how Bapedi people maintain these values for their survival. What has become clear is that ancestral beliefs contain and express the Bapedi history and culture and play an important role in the moral education of Bapedi society. It also mentions that natural environmental resources are not renewable and should be taken care of, for the benefit of the current and next generation. My investigations have led me to conclude that Bapedi society is a source of strength for indigenous knowledge systems in terms of discovery process, production and conservation.

\section{Conclusion}

This study has shown how Bapedi people utilise their natural environmental resources for their spirituality in various ways. During the study, it was observed that Bapedi people believe that the environment is the abode of ancestral spirits and ancestors. The present investigation also revealed the various ways in which the utilisation of natural environmental resources can be regulated. Indications from the investigation suggest that a research study of this kind should be taken seriously in South Africa as an exploration of indigenous values influencing learning systems. Targeting teacher educators would also be an important part of an effort to include indigenous knowledge and ways of thinking in the curriculum of both lower and higher education (Lebaka 2017:205). The body of evidence-based inquiry and research clearly demonstrate that indigenous Bapedi spirituality involves rituals, myths, ancestral beliefs and practices, perception, values and attitudes based on ancestors' experiences. Findings of the study show that taboos, myths and religious and cultural beliefs are deeply embedded in traditional Bapedi spirituality as a means of preserving Bapedi cultural heritage and identity. The present study contributes to the notion that:

The future of an African depends on the knowledge and understanding he/she acquired from the past; the wisdom of the past can be built and transformed to suit the present, which can then lead people into a prosperous future. (Axelsson 1984:62; Lebaka 2017:205)

This knowledge may help us understand the relevance of ancestral beliefs to modern Bapedi cultural practices. It is hoped that this study will fill the gap in the knowledge of 
African spirituality, traditional religion, culture and identity, theological thought and heritage.

\section{Acknowledgement}

The author is grateful to the participants of this study, who shared their knowledge on ancestral beliefs in modern cultural and religious practices of Bapedi people. The author also thanks the anonymous reviewers for their constructive comments, which he found helpful for the advancement of this research article.

\section{Author contributions}

I declare that I am the sole author of this research article.

\section{Ethical consideration}

The ethical integrity of the research was ensured through several means. The purpose of the study was explained to each participant and his or her permission sought for recording a performance or a conversation. Data collection was based on the idea of not simply extracting information from the subjects of the study but exchanging it with them. The author's approach to the conduct and reporting of his research was informed by a desire to articulate, to the best of his knowledge, the interests of the research participants, being mindful of the contexts he was working in and respecting their capacity as agents.

\section{Funding}

This research received no specific grant from any funding agency in the public, commercial, or not-for-profit sectors.

\section{Data availability statement}

Data sharing is not applicable to this article as no new data were created or analysed in this study.

\section{Disclaimer}

The views and opinions expressed in this article are those of the authors and do not necessarily reflect the official policy or position of any affiliated agency of the authors.

\section{References}

Asante, M., 1987, The Afrocentric idea, Temple University Press, Philadelphia, PA. Asante, M., 1999, The painful demise of Eurocentrism, Africa World Press, Trenton, NJ.

Asante, M. \& Asante, K., 1985, African culture, Greenwood Press, Westport, CT.

Axelsson, O., 1984, 'African music and its relation to education', Papers presented at the third and fourth Symposium of Ethnomusicology, Grahamstown, South Africa, ILAM.

Ekore, R.I. \& Lanre-Abass, B., 2016, 'African cultural concept of death and the idea of advance care directives', Indian Journal of Palliative Care (IJPC) 22(4), 369-372. https://doi.org/10.4103/0973-1075.191741

Gumo, S., Gisege, S.O., Raballah, E. \& Ouma, C., 2012, 'Communicating African spirituality through ecology: Challenges and prospects for the 21st century', MDP AG Journals 3(2), 523-543. https://doi.org/10.3390/rel3020523

Idang, G.E., 2015, 'African culture and values', Phronimon 16(2), 97-111. https://doi. org/10.25159/2413-3086/3820

Jaja, M.J., 2014, 'Myths in African concept of reality', International Journal of Educational Administration and Policy Studies 6(2), 9-14. https://doi.org/10.5897/ IJEAPS11.060

Lebaka, M.E.K., 2008, 'Myth in Africa: People in Limpopo Province', in S.A.K. Durga, R. Balasubramaniam, S.N.S. Murthy \& H.S. Sudhindra (eds.) Proceedings of International Music Conference and Festival 2008, Theme: Africa Meets Asia, Bangalore, India, July 11-16, pp. 154-160.

Lebaka, M.E.K., 2017, Transmission processes of Indigenous Pedi Music, Publishing Unit, University Library of Jyväskylä, Jyväskylä, Finland.

Leistner, E., 2014, 'Witchcraft and African development', African Security Review 23, 1-17. https://doi.org/10.1080/10246029.2013.875048

Manala, M.J., 2004, 'Witchcraft and its impact on black African Christians: A lacuna in the ministry of the Hervormde Kerk in Suidelike Afrika', Historical Theological Studies 60(4), 1491-1511. https://doi.org/10.4102/hts.v60i4.635

Mekada, J.G., 1999, 'The African-centered worldview: Toward a paradigm for socia work', Journal of Black Studies 30(2), 53-59.

Mkabela, Q., 2005, 'Using the Afrocentric method in researching Indigenous African culture', The Qualitative Report 10(1), 178-189.

Omatseye, B.O.J. \& Emeriewen, K.O., 2010, 'An appraisal of religious art and symbolic beliefs in the traditional African context', African Research Review, An International Multi-Disciplinary Journal 4(2), 529-544. https://doi.org/10.4314/afrrev.v4i2. 58370

Reck, D.B. Slobin, R.B. \& Titon, JT. 1992, 'Discovering and documenting a world of music', in J.T. Titon (ed.), Worlds of music: An introduction to the music of the world's people, pp. 39-48, Schirmer Books, Mcmillan, Inc., New York.

Santos, A., 2012, 'Theories of culture, identity, and ethnomusicology: A synthesis of popular music, cultural and communication studies', Published B.A. thesis, California Polytechnic State University, Obispo, CA.

Semenya, D.K. \& Letsosa, R., 2013, 'Effects and impact of witchcraft on Sotho reformed churches and the biblical view of witchcraft', Verbum et Ecclesia 34(1), 1-9. https://doi.org/10.4102/ve.v34i1.676

Semenya, S.S. \& Potgieter, M.J., 2014, 'Bapedi traditional healers in the Limpopo Province, South Africa: Their socio-cultural profile and traditional healing practice' Journal of EthnoBiology and EthnoMedicine 10(4), 1-15. https://doi. org/10.1186/1746-4269-10-4

Thabede, D., 2008, 'The African worldview as the basis of practice in the helping professions', Social Work/Maatskaplike Werk 44(3), 233-245.

Van Wyk, I.W.C., 2004, 'African witchcraft in theological perspective', Historical Theological Studies 60(4), 1201-1228. https://doi.org/10.4102/hts.v60i3.575

Wallace, D., 2015, 'Rethinking religion, magic and witchcraft in South Africa: From colonial coherence to postcolonial conundrum', Journal for the Study of Religion 28(1), 1-12. 